NBER WORKING PAPER SERIES

\title{
IMPACTS OF POLICY REFORMS ON LABOR MIGRATION FROM RURAL MEXICO TO THE UNITED STATES
}

\author{
Susan M. Richter \\ J. Edward Taylor \\ Antonio Yúnez-Naude \\ Working Paper 11428 \\ http://www.nber.org/papers/w11428 \\ NATIONAL BUREAU OF ECONOMIC RESEARCH \\ 1050 Massachusetts Avenue \\ Cambridge, MA 02138 \\ June 2005
}

\begin{abstract}
Paper is forthcoming in a National Bureau of Economic Research Book, to be published by University of Chicago Press, and was presented at the NBER Mexican Immigration Conference, February 2005. Richter and Taylor are Ph.D Candidate and Professor, respectively, in the Department of Agricultural and Resource Economics at the University of California, Davis, and Yúnez is Professor at the Center for Economic Studies at El Colegio de México. We gratefully acknowledge support from the William and Flora Hewlett Foundation, the U.S. Department of Agriculture (USDA/NRI), Mexico's Consejo Nacional de Ciencia y Tecnología (CONACYT), and the University of California Institute for Mexico (UCMEXUS), without which this research would not have been possible. The views expressed herein are those of the author(s) and do not necessarily reflect the views of the National Bureau of Economic Research.
\end{abstract}

(C2005 by Susan M. Richter, J. Edward Taylor, and Antonio Yúnez-Naude. All rights reserved. Short sections of text, not to exceed two paragraphs, may be quoted without explicit permission provided that full credit, including $(\mathrm{C}$ notice, is given to the source. 
Impacts of Policy Reforms on Labor Migration From Rural Mexico to the United States Susan M. Richter, J. Edward Taylor, and Antonio Yúnez-Naude

NBER Working Paper No. 11428

June 2005

JEL No. F1, J6, J4, O1

\section{$\underline{\text { ABSTRACT }}$}

Using new survey data from Mexico, a dynamic econometric model is estimated to test the effect of policy changes on the flow of migrant labor from rural Mexico to the United States and test for differential effects of policy changes on male and female migration. We find that both IRCA and NAFTA reduced the share of rural Mexicans working in the United States. Increased U.S. border enforcement had the opposite effect. The impacts of these policy variables are small compared with those of macroeconomic variables. The influence of policy and macroeconomic variables is small compared with that of migration networks, as reflected in past migration by villagers to the United States. The effects of all of these variables on migration propensities differ, quantitatively and in some cases qualitatively, by gender.

Susan M. Richter University of California, Davis srichter@primal.ucdavis.edu

J. Edward Taylor

University of California, Davis

Antonio Yúnez-Naude

El Colegio de Mexico 


\section{IMPACTS OF POLICY REFORMS ON LABOR MIGRATION FROM RURAL MEXICO TO THE UNITED STATES}

Immigrant workers from Mexico are a critical component of the supply of labor to agriculture and many non-agricultural sectors in the United States. They constitute 3.5 percent of U.S. labor force but are heavily concentrated into two types of sectors. Twenty-five percent are in services, and twenty-nine percent are involved in production and transportation occupations (Grieco and Ray, 2004). However, the majority of farmworkers are Mexico-born. According to the National Agricultural Worker Survey (NAWS), Mexico-born persons represented an estimated 77 percent of the U.S. farm workforce in 1997-98 (up from 57 percent in 1990; U.S. Department of Labor, 2000 and 1991). The majority of these workers (52 percent) were unauthorized. An overwhelming majority originate from households in rural Mexico (U.S. Commission on Immigration Reform, 1997).

Two major policy changes, The North American Free Trade Agreement (NAFTA) and the 1986 Immigration Reform and Control Act (IRCA), together with intensified enforcement along the southern U.S. border, were aimed wholly or partially at curtailing the flow of unauthorized Mexico-to-U.S. migration. The curtailment of unauthorized migration had the potential to reduce the supply of labor to these U.S. economic sectors. But these policies had potentially counteracting effects. The overall impact of NAFTA, IRCA and increased border enforcement on migration is theoretically ambiguous and therefore must be estimated econometrically.

In this paper, we estimate a dynamic econometric model to test the effect of these policy changes on the flow of migrant labor from rural Mexico to the United States. Recognizing that policy changes may have differential effects on male and female labor migration, we estimate the effects of policy changes by the gender of migrant flows, as well. The models are estimated using retrospective data from the 2003 National Mexico Rural Household Survey.

\section{Conceptual Framework}

Given individual, household and community characteristics, policy changes may alter the larger milieu within which migration decisions take place. In this paper we isolate the impact of three policies, IRCA, NAFTA and increased expenditure on enforcement along the U.S.-Mexican border. Each of these policies has counteracting effects on migration, making the overall impact on migration ambiguous.

IRCA had two main components. First, it made employers who hired illegal aliens subject to fines and/or imprisonment. These penalties were meant to discourage the hiring of unauthorized immigrants and reduce migration by dampening the employment expectations of migrants. Second, IRCA provided amnesty to illegal aliens who have lived in the U.S. continually since 1982, if they applied before 1988. This policy legalized U.S. migration contacts for households throughout rural Mexico. In so doing, it may have encouraged migration by family members of newly legalized migrants, while also sending a signal to rural Mexicans that future amnesty deals might be forthcoming. Therefore, these two components of IRCA potentially have counteracting effects on immigration. 
NAFTA was only partially motivated by migration concerns but was expected to have far-reaching impacts on migration flows. In the long run, trade liberalization policies open North American markets to Mexico, encouraging export of goods and decreasing migration pressures. ${ }^{1}$ That is, in the long run, trade and migration may be substitutes. After Mexico joined NAFTA, Mexican agricultural exports to the United States did, indeed, increase. However, in the short run, NAFTA could displace rural workers as production shifts from importables to exportables and labor markets adjust to new market realities. Computable general equilibrium models predicted that the increase in labor demand generated by exports to the United States would be insufficient to absorb workers displaced from agricultural activities that had been protected by government policies prior to NAFTA. This, in turn, would stimulate out-migration from rural Mexico (Levy and and van Wijnberger: 1992, and Robinson et.al.: 1991).

The process of dismantling protectionist agrarian policies, which began just prior to NAFTA, was also expected to displace agricultural workers throughout Mexico. Mexico phased out price supports for eleven agricultural field crops and the processing, storing, and marketing activities of the state-run National Company of Popular Subsistence (CONASUPO, Yunez-Naude: 2003). Agricultural credit subsidies were also reduced sharply (Yunez and Barceinas: 2004). For rural workers displaced by policies related to NAFTA, migration may have been a vehicle to overcome short term financial shocks.

The third policy that we evaluate is the increase in enforcement along the U.S. Mexico border. Increases in border enforcement were meant to curtail unauthorized immigration. However, they could have the opposite effect, by discouraging unauthorized immigrants from returning to their home countries and thus extending their stays in the United States. Increased border enforcement raises smuggler fees, but family members may be willing to pay the increased cost in order to reunite with relatives who have extended stays in the United States.

The possible impacts of these three policies on migration are complex and theoretically ambiguous. The net effects of these policy shocks on the migration of labor from rural Mexico to the United States can only be determined empirically. However, in order to isolate the effects of policy changes on migration we also need to control for the plethora of individual, household and community variables influencing migration decisions over time, as well as macroeconomic shocks that affect the migration decision.

Individual, household and community variables affect the costs and benefits of migrating relative to staying at home and thus the propensity to migrate. The propensity to migrate and obtain employment in the United States is partly a function of migration networks and sending-area characteristics. Sending-area characteristics and community level heterogeneity are controlled for econometrically via fixed effects, while migration networks or contacts with employed migrants in the United States are represented by lagged stocks of employed villagers in the United States. Networks may be genderspecific. For example, females may base their migration decision on the knowledge that other females in the village have succeeded in crossing the border and obtaining employment in the United States. In order to evaluate gender-specific network effects we include separately the lagged stocks of male and female villagers employed in the United States.

\footnotetext{
${ }^{1}$ Presidents Salinas and Bush (Senior) argued this point to gain support for NAFTA.
} 
Several macroeconomic variables also may influence the benefits and costs of international migration. These variables include changes in the peso-dollar exchange rate and in per-capita GDPs of both countries. Mexican currency devaluations increase the purchasing power of dollars remitted in Mexico. Changes in U.S. GDP are included as a proxy for the availability of jobs in the United States. They are expected to be positively related to migration. The impact of an increase in Mexico's GDP is ambiguous. On one hand, it could reflect employment growth that discourages migration. On the other hand, higher income in Mexico could provide households with the liquidity to finance investments, including investments in international migration, i.e., the costs associated with crossing the U.S.-Mexican border and establishing oneself in a foreign labor market. Our econometric analysis controls explicitly for these variables in order to isolate the impact of our three policy variables.

\section{Theoretical Model}

At the micro level, international migration is only observed for households and family members that choose to participate in migration, which is a discrete decision. Migrants are individuals for whom the expected benefits of migration, R, exceed the (unobserved) migration "reservation wage," $\omega$. The migration reservation wage depends on local opportunities on and off the farm. Following Mincer, the local wage is a function of human capital that affects the marginal productivity of labor. Let $\mathrm{X}_{\mathrm{W}}$ denote a vector of human capital characteristics influencing wage income in the local labor market. The productivity of family members' on local farm and off-farm activities is shaped both by these human capital variables and by family assets $\bar{K}$. Remittances are a function of migrants' human capital, which affects earnings, as well as migrants' motivations to remit, which may be influenced by both human capital and family assets (Lucas and Stark, Taylor, 1985). Contacts at migrant destinations, $\overline{M K}$, are a form of migration capital that can enhance the labor-market prospects of migrants (Munshi, 2003).

Migrant remittances and reservation wages have both deterministic and stochastic components; thus, $R=R\left(X_{R}\right)+u$ and $\varpi=\varpi\left(X_{\varpi}\right)+v$, where $X_{\varpi}=\left[X_{W}, \bar{K}\right]$, $X_{R}=\left[X_{W}, \bar{K}, \overline{M K}\right]$, and $u$ and $v$ are stochastic errors. Letting $\delta_{i}=1$ if household member i migrates and 0 otherwise, the migration participation decision becomes:

$$
\delta_{i}=\left\{\begin{array}{cc}
1 & \text { if } \eta_{i}<R\left(X_{R}\right)-\sigma\left(X_{\varpi}\right) \\
0 & \text { otherwise }
\end{array}\right.
$$

where $\eta_{i}=v_{i}-u_{i}$. Total migration is simply the sum of individuals who migrate; that is, $M=\sum_{i} \delta_{i}$. Let $\theta_{t}$ represent the joint distribution of variables $X_{R}$ and $X_{\sigma}$ in community $\mathrm{j}$ at time t. Then

$$
M_{j t}=M\left(\theta_{j t}, Z_{j t}\right)
$$

where $Z_{j t}$ is a vector of community variables influencing the productivity of labor in local activities and remittances. In the econometric model, we control for the influences of $\theta_{j t}$ and $Z_{j t}$ by including lagged migration $\left(M_{j, t-1}\right)$, fixed effects for communities, and a time trend. 


\section{Data}

The data used to estimate the model are from a nationwide rural household survey carried out jointly by El Colegio de Mexico and the University of California, Davis. The Mexico National Rural Household Survey (Encuesta Nacional a Hogares Rurales de Mexico, or ENHRUM) provides retrospective data on migration by individuals from a sample of rural households that is both nationally and regionally representative (see http://precesam.colmex.mx). Past studies of Mexican labor supply to the U.S. employment sectors used proxies including border apprehensions (e.g., Torok and Huffman: 1986) or data from surveys of small numbers of villages. Usually surveys have not collected migration flows over extended periods of times and thus are unable to evaluate policies' long-term impact on the dynamics and trends of migration. We hope that our dataset will fill this lacuna in the literature.

The ENHRUM was carried out in January and February 2003 in all of Mexico's five census regions (See Figure 1). INEGI (Instituto Nacional de Estadística, Geografía e Informática), Mexico's national census office, designed the sampling frame to provide a statistically reliable characterization of Mexico's population living in rural areas, defined by INEGI as communities with fewer than 2,500 inhabitants. The survey was designed to be representative both nationally and regionally. Rural households were selected via a three-tiered stratified random sampling method involving states, communities, and households randomly drawn within each community. This method generated a sample of 1,782 households in 80 villages and 14 Mexican states. For reasons of cost and tractability, individuals in hamlets or disperse populations with fewer than 500 inhabitants were not included in the survey. The sample is representative of more than 80 percent of the population that the Mexican census office considers to be rural.

The ENHRUM survey assembled complete migration histories from 1980 through 2002 for (a) the household head, (b) the spouse of the head, (c) all individuals who lived in the household 3 months or more in 2002, and (d) a random sample of sons and daughters of either the head or his/her spouse who lived outside the household longer than 3 months in 2002. In theory, the ENHRUM survey collected retrospective information only about labor migrants. ${ }^{2}$ However, data on place of residence of all family members were gathered for 2002, regardless of employment status. For 2002, virtually all migrants were considered by family members in the village to be labor migrants. If the same is true for earlier years, our counts of labor migrants will also reflect total migration. For each year, the survey provides information on the migrant's sector of employment, agricultural or non-agricultural, and the state in which he/she worked. The survey provides the most reliable longitudinal data on migration from rural Mexican communities to the United States.

The survey asked individuals to recall employment information for each migrant from 1980-2002. Individuals may be unable to remember their (or their migrant sons' and daughters') employment histories for 22 years. However, when employment is coupled with a life event such as international migration, there is a smaller likelihood that

\footnotetext{
${ }^{2}$ The questions asked in the survey were: “¿Qué años trabajó __ en los E.U. desde 1980? ¿En qué trabajó y en qué estado? ¿Por un salario o por cuenta propia?" ("In what years did 1980 ? In what job and which state? For a salary or self-employed?"). work in the U.S. since
} 
data will be misreported. A study by Smith and Thomas (2003) showed that when respondents are asked to recall information linked to salient events, such as marriage or birth of a child, misreporting is insignificant. Also, individuals asked to recall labor or migration histories reported more accurately moves that involved either a long distance or extended stays.

To implement the survey, Mexico was divided into 5 regions, reflecting INEGI's standard regionalization of the country: Center, South-Southeast, Center-West, Northwest, and Northeast. ${ }^{3}$ Table 1 summarizes migration from households in rural Mexico. Sixteen percent of all households in the sample had a family member living in the United States at the start of 2002, the year of the survey, and 26 percent had a family member living in another part of Mexico. Many households had more than one migrant. The number of U.S. migrants per household ranged from 0 to 9 , while the number of internal migrants ranged from 0 to 10 . The average household in the sample had 0.35 U.S. migrants and 0.71 internal migrants in 2002-or 1.06 migrants in total.

As indicated in the Table, there are sharp differences in migration experience among the five rural regions. West-Central Mexico traditionally has been the largest sender of migrants to the United States, with far and away the highest current participation in international migration and the most international migration experience. In this region, nearly $28 \%$ of all households have at least one family member in the United States, and the average household had .62 U.S. migrants. By contrast, $7.5 \%$ of households in the south-southwest have U.S. migrants, with an average of .10 U.S. migrants per household.

\section{Econometric Model}

We econometrically estimate the impact of policy reforms for three dependent variables: 1) the share of villagers employed in the U.S.; 2) the share of female villagers employed in the U.S.; and 3) the share of male villagers employed in the U.S.

For the first dependent variable we estimate two fixed-effects panel data models for all employed immigrants. The first model is intended to capture the basic dynamics of rural Mexico-to-U.S. migration. The share of village population observed as labor migrants in the Untied States at time t, $M_{t}$, is regressed on the same share lagged one year $\left(M_{j t-1}\right)$ and a time trend $(t)$, controlling for a vector of village fixed effects, $\alpha_{j}{ }^{4}$

$$
M_{j t}=\alpha_{j}+\gamma+\delta M_{j t-1}+u_{j t}
$$

Essentially, equation (3a) estimates the dynamic nature of employed migration over time and allows us to evaluate the role of networks and the inertia of employed migration over time. Village fixed effects, $\alpha_{j}$, control for community-specific migration dynamics that

\footnotetext{
${ }^{3}$ The high-migration West-Central region was the focus of Mexico Migration Project (MMP) surveys (Population Studies Center, University of Pennsylvania, Philadelphia (producer and distributor), www.pop.upenn.edu/mexmig/welcome.html). The MMP surveyed a random sample of households within communities, but the sample of MMP communities was not random.

${ }^{4}$ We use the percentage rather than the sum of villagers who migrated because of our concern that the size of village populations in the synthetic cohorts created using retrospective data is biased downward as one goes back in time, as individuals are removed from the population due to death (and thus are not available to be counted in 2003).
} 
shape the migration trend; each village is permitted to have its own migration trajectory. The village fixed-effects model makes it possible to isolate the underlying migration trend ( $\mathrm{t}$ ) and influence of networks and inertia (the lagged-migration variable) from policy and macroeconomic variables shaping migration.

Model two includes three policy variables: dummy variables for IRCA (1 for all time periods beginning in 1986, the year of IRCA's implementation) and NAFTA (1 beginning in 1994, 0 before), and a continuous variable measuring the percentage change in border enforcement expenditures $\left(\triangle B E_{t}\right)$. We also include macroeconomic variables: the percentage changes between time $\mathrm{t}$ and $\mathrm{t}-1$ in the peso-dollar exchange rate $\left(\Delta E R_{t}\right)$ and the US and Mexico GDPs $\left(\triangle U S G D P_{t}, \Delta M G D P_{t}\right)$.

$$
\begin{aligned}
& M_{j t}=\alpha_{j}+\gamma t+\delta M_{j t-1}+\beta_{1} I R C A_{t}+\beta_{2} N A F T A_{t t}+\beta_{3} \Delta B E_{t} \\
& +\theta_{1} \Delta E R_{t}+\theta_{2} \Delta U S G D P_{t}+\theta_{3} \Delta M G D P_{t}+u^{\prime \prime}{ }_{j t}
\end{aligned}
$$

Our use of dummy variables to evaluate the impact of NAFTA and IRCA warrants some explanation. Other methods are possible, including controls for trade flows or changes in real wages in Mexico and the U.S. But these variables may not be exogenous to migration. For example, changes in real agricultural wages in the United States clearly are related to the supply of migrant labor from rural Mexico. The inclusion of policy dummy variables in the regressions makes it possible to evaluate the long run impact of exogenous policy shocks on the rate and dynamic of labor migration. Inclusion of the lagged-migration variable allows for the impacts of policy shocks to unfold gradually over time. The vector of fixed effects, $\alpha_{j}, \delta, \beta_{k}, k=1, \ldots, 3$ and $\theta_{l}, l=1, \ldots, 4$ are parameters to be estimated, and $u_{j t}, u^{\prime}{ }_{j t}$, and $u^{\prime \prime}{ }_{j t}$ are stochastic errors. The use of migration shares $\left(M_{j t}\right)$ instead of differences in migration shares between periods $\left(M_{j t}-M_{j t-1}\right)$ as the dependent variable allows for the possibility that $\delta \neq 1$. Under the null hypothesis of no policy impacts on migration the coefficients $\beta_{k}=0 \forall \mathrm{k}$.

We estimate three types of dynamic fixed-effects models for labor migration by gender $(g=m, f)$. The first model is similar to equation (3a). We estimate the share of males (females) in employed migration as a function of a time trend $(\mathrm{t})$ and the lagged share of male (female) migrants in village populations:

$$
M_{j g t}=\alpha_{j}+\gamma t+\delta_{1} M_{j g t-1}+u^{\prime \prime}{ }_{j t}
$$

We re-estimated each equation including the lagged stock of other-gender migrants to evaluate the gender sensitivity of networks:

$$
M_{j s g t}=\alpha_{j}+\gamma t+\delta_{1} M_{j m t-1}+\delta_{2} M_{j f t-1}+u^{\prime \prime}
$$

If both male and female networks shape female migration, then both $\delta_{1}$ (lagged-female migration) and $\delta_{2}$ (lagged-male migration) will be significant, and conversely for the male migration regression.

In the final estimation we include, in each gender-specific migration equation, all our policy and macroeconomic variables. This model is similar to equation (3b) except that it includes the lagged stock of other gender's participation in employed migration:

$$
\begin{aligned}
M_{j s g t}= & \alpha_{j}+\gamma t+\delta_{1} M_{j m t-1}+\delta_{2} M_{j f t-1}+\theta_{1} \Delta I R C A_{t}+\theta_{2} \Delta N A F T A_{t} \\
& +\theta_{3} \Delta B E_{t}+\beta_{1} \Delta E R_{t}+\beta_{2} \Delta U S G D P_{t}+\beta_{3} \Delta M G D P_{t}+u^{\prime \prime}{ }_{j t}
\end{aligned}
$$




\section{Estimation and Results}

The series of models given by 3(a)-3(b) and 4(a)-4(c) was estimated using the standard least square dummy variable (LSDV) method. This method results in a downward bias in the estimate of $\delta$; however, this bias diminishes as the number of observations in the time dimension (T) increases (Judson and Owen, 1999). Judson and Owen show that the bias becomes negligible as $\mathrm{T}$ approaches 30. In our dataset, $\mathrm{T}=23$ (1980-2002, inclusive), which indicates that there will be some bias, but it will be small. Judson and Owen also conclude that when $\mathrm{T}$ is greater than 20 the bias in the other parameter estimates is negligible. The key hypotheses that we wish to test involve not $\delta$, but rather, the other parameters in the model (i.e., the effects of policy variables).

Figure 2 presents estimated shares of populations from the surveyed villages in U.S. farm and nonfarm jobs from 1980 to 2002. It shows an upward trend in migration to the United States for both males and females. However the trend is steeper for males than females. ${ }^{5}$ Female migration is steady, lower than male migration, and has a steady increase over the 23 -year period. Table 2 presents variable definitions and means for variables used in the econometrics.

The data set for this sample provides information on migration from 80 villages over 23 years (from 1980 to 2002); however, one year (80 observations) was lost as a result of lagged right-hand-side variables. Thus, the total sample size is 1,760 (22 years $\mathrm{x}$ 80 villages).

Table 3 reports the econometric results for the village share of labor migrants using ordinary least squares, controlling for fixed effects. Column 1 of Table 3 shows results from the model that only controls for the lagged stock of migration. The time trend is significant and positive. The coefficient on lagged migration is also significant and positive, indicating that networks created through past migration influence current migration.

Macroeconomic variables and policies, such as NAFTA and IRCA, can change the overall trend and influence of migration rates. Results from Model 2, which includes these variables, are reported in column 2 of Table $3^{6}$. The time trend and coefficient on lagged migration remain positive, large and significant. The dummy variables for NAFTA and IRCA have a significant and negative impact on migration. Therefore, the supply of migrant labor from rural Mexico to the U.S. decreases after the implementation of IRCA in 1982, and it decreases once again following NAFTA in 1994. These findings support the hypothesis that NAFTA relieved migration pressures. IRCA also curtailed migration, but to a smaller degree than NAFTA. In contrast to these policies, the increase in border enforcement increased the share of villagers working in the United States. This finding supports the hypothesis that migrants continue to enter the U.S. and/or that increased border enforcement discourages return migration.

\footnotetext{
${ }^{5}$ The surge in migration to the United States in the 1990s is mirrored in U.S. Census 2000 data. The U.S. Census does not provide information on where migrants originate in Mexico (e.g., from rural or urban areas). However, they show an unexpectedly large increase in Mexico-born persons living in the United States.

${ }^{6}$ Trends in migration may also be influenced by regional dynamics. When separate repressors are estimated for Mexico's five census regions, there were no differences in the signs of significant variables among regions for all of the models presented in this paper.
} 
The macroeconomic variables are all significant and larger in magnitude than the policy variables. The devaluation of the peso increases the rate of migration. This is of the expected sign, inasmuch as the devaluation raises the returns to migration (remittances) in pesos. Changes in both country GDPs increase migration. Economic expansion in the U.S. pulls rural Mexicans into the country. GDP growth in Mexico encourages migration. This finding is consistent with the argument that income growth enables rural households to finance the cost of crossing the border and establishing migrants in U.S. labor markets.

Gender-specific regression results appear in Table 4, for female migrants, and Table 5, for male migrants. The column labeled "Model I" in each table shows results for the basic dynamic regression model. When we estimate the migration model by gender, the trend remains significant and positive but flat. However, the lagged migration participation rate is both statistically and quantitatively significant. When the lagged migration rate of males is added to the estimate of female migration (Model II in Table 4 ), it has no significant impact. That is, there is no evidence of significant cross-gender network effects on female migration. The effect of lagged female migration on male migration (Table 5) is positive and significant at the $10 \%$ level, but it is quantitatively small. A one-percentage-point increase of the share of village females working in the United States, other things being equal, is associated with a .07-percent increase in male participation in international migration. This finding suggests that labor migration networks are gender specific. That is, estimates of a gender's participation in labor migration do not improve appreciably when the other gender's migration network is included in our regressions.

Macroeconomic and policy variables (Model II in Tables 4 and 5) significantly increase the predicative power of the migration models for both genders. ${ }^{7}$ Qualitatively, policy changes have similar effects on male and female migration, with the exception of GDP growth. However, quantitatively the results differ according to gender. The decrease in the male migrant share after NAFTA is three times greater than the drop in the female share. This suggests that female migration was more resilient to NAFTArelated policy changes. The decrease in migration shares after implementation of IRCA is twice as large for males as females. Other things being equal, a 1-percent increase in U.S. border enforcement has a larger positive percentage effect on male migration than on female migration (.022 and .010 , respectively). This indicates either that border enforcement increases male stays more than female stays, or perhaps more plausibly, that border controls are more of a deterrent to border crossings by females than males.

The effects of changes in Mexico's GDP are significant only for female migration. By contrast, changes in US GDP are significant only for male migration. These findings may suggest that female migration is more sensitive to liquidity constraints that can be loosened by income growth in Mexico, while female migrant labor demand is robust to U.S. GDP growth. Male migration, on the other hand, appears to be sensitive to U.S. economic growth.

\footnotetext{
${ }^{7}$ An F test of restricted versus unrestricted regressions, for both male and female migration shares rejected the joint hypothesis that the macroeconomic and policy variables were jointly zero.
} 


\section{Limitations and Caveats}

Reliance on policy dummy variables and retrospective data to test for effects of policy changes on migration raises some questions and concerns that should be kept in mind when interpreting the findings presented here.

It might be argued that policy changes were endogenous responses to increasing migration in the period covered by our analysis. However, the build-up to IRCA was gradual and commenced several years prior to the period covered by our analysis. Sanctions were enacted by the U.S. House of Representatives twice in the early 1970s but subsequently blocked in the Senate. President Carter proposed sanctions against employment of unauthorized immigrants and legalization in 1977. Following several years of debate and the establishment of the Select Commission on Immigration Reform, IRCA was finally passed in 1986. It might also be argued that IRCA was a response to economic recession, which in turn could be correlated with immigration. However, by the time IRCA was passed, the early 1980s recession was largely over. There was more unauthorized Mexico-to-U.S. migration after 1982-83 recession, and migration accelerated in the 1990s (Martin, 2003, Chapter 7).

Our analysis uses fixed effects to control for unobserved village characteristics on migration. It might be argued, however, that the effects of IRCA and NAFTA on migration probabilities varied across regions. IRCA's effects may have been different in rural areas in which the prevalence of migration was high prior to the policy's implementation. NAFTA's influence on migration may have been different in regions with high agricultural potential or high levels of industrialization. How these regional characteristics might have influenced migration is not clear a priori. For example, the influence of a large manufacturing sector on NAFTA's migration effects could be positive (in the case of internationally competitive industries) or negative (in the case of industries that were protected by Mexican trade policies prior to NAFTA). A high prevalence of migration prior to IRCA could reflect a region's vulnerability to immigration reforms or an enhanced ability to adapt to reforms, for example, through amnesty programs. A rich agricultural base could reflect opportunities for expanding agro-exports post-NAFTA; however, labor-saving technological change is concentrated on high-potential lands. To explore the sensitivity of policy findings to regional conditions, we re-estimated the model including, as explanatory variables, interactions between:

- IRCA and the share of villagers who were international labor migrants in 1980

- NAFTA and the share of cultivated land that was irrigated in 1980

- NAFTA and the share of manufacturing in state GDPs in 1980

We chose 1980 values for these variables to minimize possible endogeneity bias. In no case was an interaction term significant in explaining migration probabilities. Inclusion of these interactions did not qualitatively alter the effects of the policy variables presented earlier.

A number of other economic and policy changes were more or less coincident with IRCA and NAFTA. Foremost among these were the peso devaluation of late 1994 and 1995 and enactment of a major welfare reform in the United States in 1996. 
We attempt to disentangle the effects of currency devaluations from those of policy shocks by including changes in the peso-dollar exchange rates in our regression. The 199495 period saw a sharp increase in this exchange rate. However, this was not the only period of significant devaluation in our time series. We believe that there is sufficient variation in our exchange-rate variable from 1980 to 2002 to control for currency effects.

Other policies that could have affected immigration were enacted within several years of IRCA and NAFTA. Foremost among these was the Personal Responsibility and Work Opportunity Reconciliation Act of 1996 (PL 104-193, PRWORA), which singled out immigrants. Most legal immigrants arriving after August 22, 1996 are not eligible for federal welfare assistance until they have been in the United States for at least five years, and many legal immigrants receiving assistance when PRWORA was enacted lost their eligibility for benefits. Enacted only two years after NAFTA, PRWORA's effects could conceivably contaminate our findings, if restricting immigrants' access to benefits created a deterrent to immigration. In a study of agricultural counties in California, Green, et al. (2003) found that PRWORA reduced the number of adults receiving cash assistance; however, controlling for employment and other variables, the estimated effect of the policy change was not large. Borjas (2002) concluded that much of the potential impact of welfare reform on immigrants outside of California was undone by the actions of state governments. Many states - particularly those with large immigrant populations - chose to offer stateprovided benefits to otherwise ineligible immigrants. Empirical studies overwhelmingly point to employment and wages as the primary drivers of immigration. These considerations raise doubts about the extent to which welfare reform influenced immigration.

Due to mortality, some (mostly older) individuals disappear from our synthetic cohorts of migrants and villagers as we go back in time - that is, they are not alive to be counted at the time of the survey. If old villagers are less likely to migrate, this will result in an upward bias in the estimated share of villagers in the United States (and thus a downward bias in the estimated migration trend), and this bias will be larger the farther back in time one goes. The key question relevant to our analysis is whether this bias alters the estimated effect of policy changes on migration. We explored this possibility by estimating the model separately for younger age cohorts of villagers (i.e., those who were 16-35 years old in 1980 and thus less at risk of being affected by mortality over the study period). There were no significant changes to our econometric findings. Our findings on the effects of policy reforms on migration appear to be robust to the ways in which we construct our synthetic cohorts.

\section{Conclusions}

The impacts of NAFTA, IRCA and increased U.S. border enforcement are ambiguous apriori. Each policy change potentially has both positive and negative influences on migration. In the past, data limitations have made it difficult to test for impacts of policy shocks on Mexico-to-U.S. migration dynamics. The Mexico National Rural Household Survey provides retrospective migration histories from a nationally random sample of rural Mexicans. This makes it possible to isolate migration trends and control for placeof-origin characteristics while measuring the impacts of policy shocks on the share of rural Mexicans working in the United States. 
Several general findings emerge from our analysis. First, international labor migration from rural Mexico has followed an upward trend from 1980-2002 but is driven overwhelmingly by past migration, reflecting the central role of migration networks. Second, policy variables significantly influence migration, but not as much as macroeconomic variables. NAFTA and IRCA had some impact on curtailing migration; however, increased border enforcement appears to have the opposite effect. No policies are able to counteract the effects of a changing macroeconomic environment. Third, the influences of both policy and macroeconomic variables are small compared with network effects embodied in past migration.

A unique contribution of this analysis is the insight it offers into the dynamics underlying female and male migration. Policy shocks and macroeconomic variables have differential effects on female and male migration, quantitatively (in the case of NAFTA and IRCA) and in some cases qualitatively (in the case of Mexico and U.S. GDP growth). The role of Mexico GDP growth in loosening liquidity constraints on migration appears to be more important for females than males, while the impact of U.S. income growth is greater for males.

Although own-gender migration networks are significant and large, cross-gender network effects are small or nonexistent. Past research has suggested that female migrants follow males, for example, for purposes of family reunification. However, we find that past labor migration by male villagers has no significant effect on female labor migration. That is, controlling for community effects and long run migration dynamics, labor migration networks are gender specific. Future economic research is warranted on gender asymmetries in networks and their influence on migration propensities. 

REGIONES Y DISTRIBUCIÓN GEOGRÁFICA DE COMUNIDADES ENCUESTADAS

Figure 1:

ENHRUM 2003 Regions

and Distribution of

Communities Surveyed

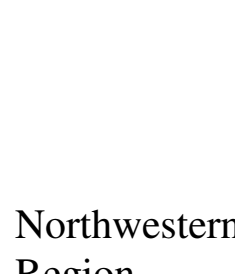

Region

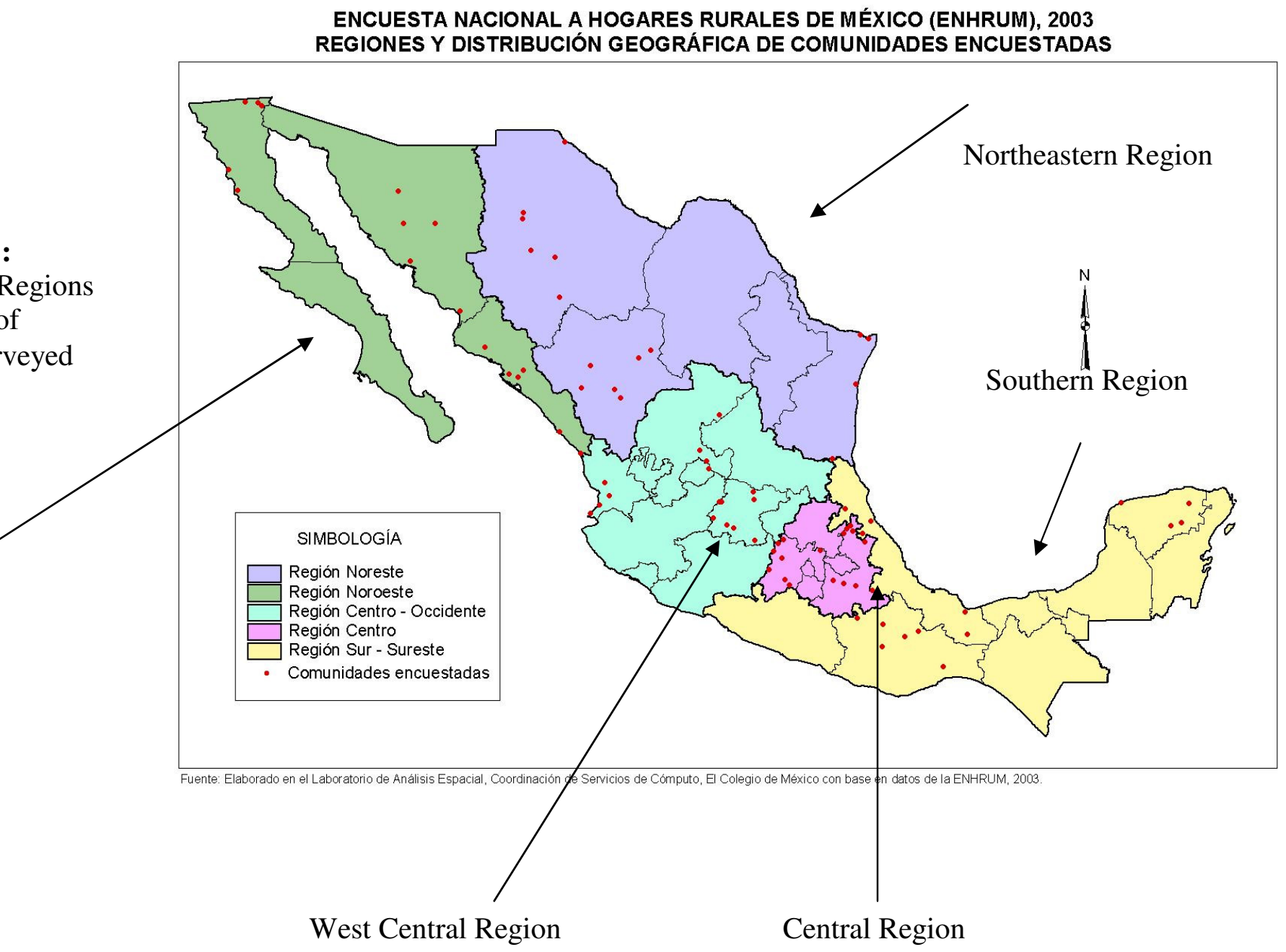


Figure 2: Average Share of Villagers Employed in United States: 1980-2002

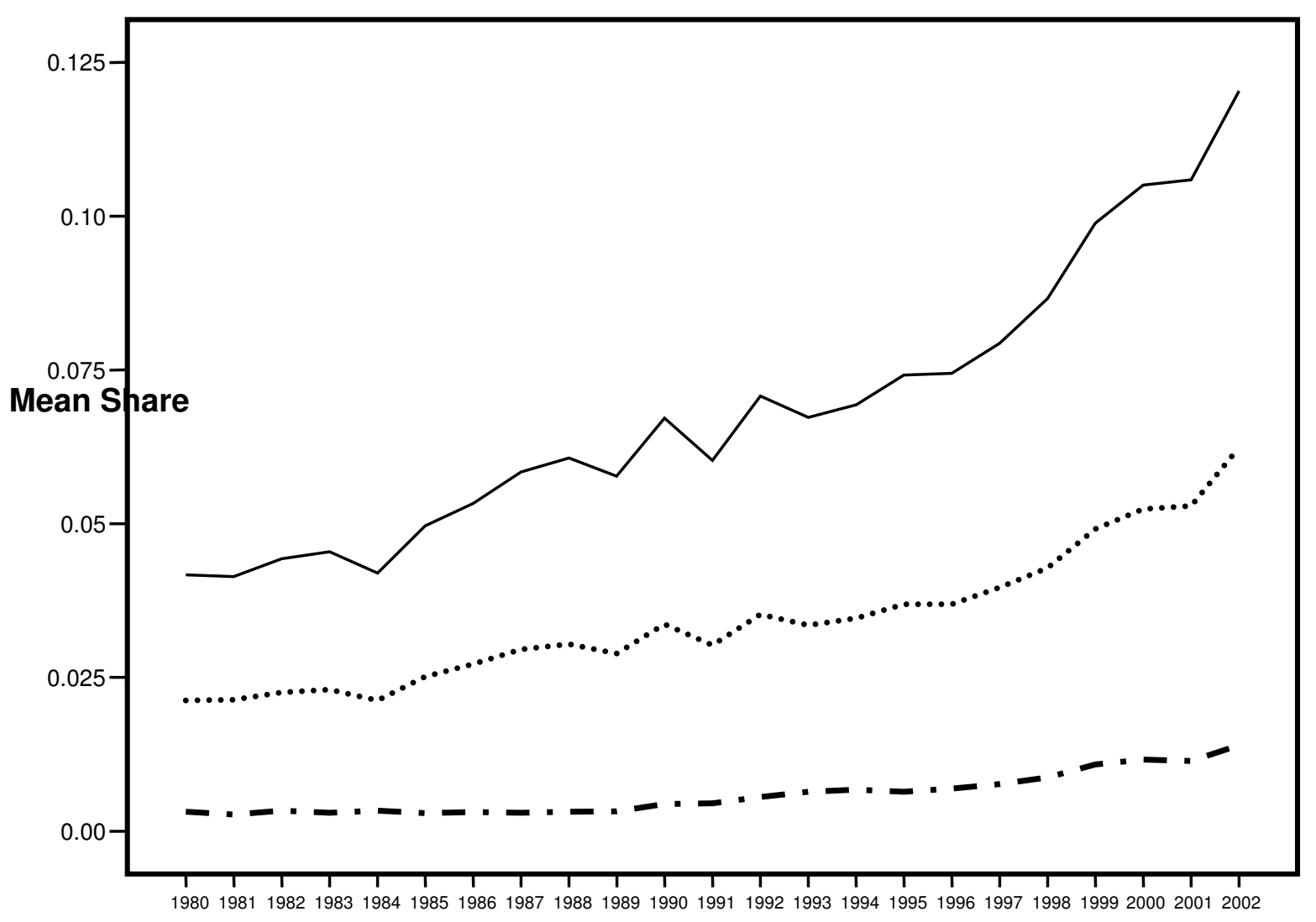

Año

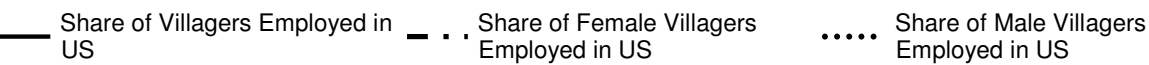


Table 1. Migration Summary Statistics for Rural Mexico, by Region

\begin{tabular}{|c|c|c|c|c|}
\hline Region & Variable & Percentages & Sample Mean & Standard Deviation \\
\hline \multirow[t]{3}{*}{ South-South East } & Households with US migrants (\%) & $7.53 \%$ & - & 0.26 \\
\hline & US Migrants per Household & & 0.10 & 0.42 \\
\hline & Household Sample Size & & 372 & \\
\hline \multirow[t]{3}{*}{ Center } & Households with US migrants (\%) & $14.52 \%$ & - & 0.35 \\
\hline & US Migrants per Household & & 0.27 & 0.89 \\
\hline & Household Sample Size & & 365 & \\
\hline \multirow[t]{3}{*}{ Center-West } & Households with US migrants (\%) & $27.75 \%$ & - & 0.45 \\
\hline & US Migrants per Household & & 0.62 & 1.29 \\
\hline & Household Sample Size & & 346 & \\
\hline \multirow[t]{3}{*}{ Northwest } & Households with US migrants (\%) & $12.09 \%$ & - & 0.33 \\
\hline & US Migrants per Household & & 0.23 & 0.79 \\
\hline & Household Sample Size & & 339 & \\
\hline \multirow[t]{3}{*}{ Northeast } & Households with US migrants (\%) & $19.72 \%$ & - & 0.40 \\
\hline & US Migrants per Household & & 0.54 & 1.43 \\
\hline & Household Sample Size & & 360 & \\
\hline \multirow[t]{3}{*}{ Total } & Households with US migrants (\%) & $16.22 \%$ & - & 0.37 \\
\hline & US Migrants per Household & & 0.35 & 1.04 \\
\hline & Household Sample Size & & 1782 & \\
\hline
\end{tabular}


Table 2. Variable Definitions and Means

\begin{tabular}{|c|c|c|}
\hline Variable & Description & Mean \\
\hline $\mathrm{T}$ & Time Trend & 11 \\
\hline USMIG & $\begin{array}{l}\text { Share of Villagers } \\
\text { Employed in U.S. }\end{array}$ & .0403 \\
\hline Female Migration & $\begin{array}{l}\text { Share of Female Villagers } \\
\text { Employed in U.S. }\end{array}$ & .0059 \\
\hline Male Migration & $\begin{array}{l}\text { Share of Male Villagers } \\
\text { Employed in U.S. }\end{array}$ & .0344 \\
\hline$\%$ Change ER & $\begin{array}{l}\% \text { change in Peso-Dollar } \\
\text { exchange rate from } \\
\text { previous year }\end{array}$ & 11.4 \\
\hline$\%$ Change Border Control & $\begin{array}{l}\text { \% change in INS border } \\
\text { enforcement budget from } \\
\text { previous year }\end{array}$ & 13.8 \\
\hline NAFTA & $\begin{array}{l}\text { Dummy variable }=1 \\
\text { beginning in } 1994\end{array}$ & 0.39 \\
\hline IRCA & $\begin{array}{l}\text { Dummy variable }=1 \\
\text { beginning in } 1986\end{array}$ & 0.74 \\
\hline$\%$ Change MGDP & $\begin{array}{l}\text { \% change Mexico per capita } \\
\text { GDP }\end{array}$ & 2.5 \\
\hline$\%$ Change US GDP & $\begin{array}{l}\text { \% change US per capita } \\
\text { GDP }\end{array}$ & 3.0 \\
\hline
\end{tabular}


Table 3.

OLS Coefficients for three Dynamic Models-Participation in Migration (USMIG (US $_{\mathbf{t}}$ (standard errors in Parenthesis)

$\begin{array}{lcc} & & \text { All Regions } \\ \text { Variables } & \text { Model I } & \text { Model II } \\ \text { Constant } & -.006 & -.013 \\ \text { T } & (.003)^{* *} & (.004)^{* *} \\ & .001 & .001 \\ \text { USMIG } & (.000)^{* *} & (.000)^{* *} \\ & .846 & .845 \\ \text { NAFTA } & (.015)^{* *} & (.015)^{* *} \\ & & -.008 \\ \text { IRCA } & & (.002)^{* *} \\ \text { \% Change } & & -.003 \\ \text { Border } & & (.001)^{* *} \\ \text { Control } & & .011 \\ \% \text { Change } & & (.003)^{* *} \\ \text { ER } & & .015 \\ \% \text { Change } & & (.004)^{* *} \\ \text { MGDP } & .034 \\ \% \text { Change } & & (.016)^{* *} \\ \text { US GDP } & & .051 \\ \mathrm{R}^{2} & & (.022)^{* *} \\ \text { Dependent Variable: Weighted total of international workers in village } \\ \text { All models were estimated with village fixed effects. } \\ \text { N=1759. **Significance at .05 level * Significance at .1 level } & .948 \\ & & \\ & & \end{array}$


Table 4.

OLS Coefficients for three Dynamic Models-Female Participation in Migration (Female USMIG $_{t}$ ) (standard errors are in parentheses)

Variables

Constant

$\mathrm{T}$

Female $\mathrm{USMIG}_{\mathrm{t}-1}$

Male $\mathrm{USMIG}_{\mathrm{t}-1}$

NAFTA

IRCA

$\%$ Change Border

Control

$\%$ Change ER

$\%$ Change MGDP

$\%$ Change US GDP

$\mathrm{R}^{2}$
All Regions

$$
\begin{gathered}
\text { Model I } \\
-.001 \\
(.001) \\
.000 \\
(.000)^{* *} \\
.881 \\
(.014)^{* *}
\end{gathered}
$$

Model II

$-.003$

$(.001)^{* *}$

.000

$(.000)^{* *}$

.874

$(.015)^{* *}$

.007

$(.008)$

$-.002$

$(.001)^{* *}$

$-.001$

$(.000)^{*}$

.002

$(.001)^{* *}$

.003

$(.001)^{* *}$

.011

$(.005)^{* *}$

.009

$(.007)$

.883

Dependent Variable: Weighted total of female international workers in village All models were estimated with village fixed effects.

$\mathrm{N}=1759$. $* *$ Significance at .05 level * Significance at .1 level 
Table 5

OLS Coefficients for three Dynamic Models-Male Participation in Migration (Male USMIG $_{\mathbf{t}}$ ) (standard errors are in parentheses)

\begin{tabular}{|c|c|c|}
\hline \multirow[b]{2}{*}{ Variables } & \multicolumn{2}{|c|}{ All Regions } \\
\hline & Model I & Model Il \\
\hline Constant & -.005 & -.010 \\
\hline Constant & $(.003)^{*}$ & $(.003)^{* *}$ \\
\hline & .000 & .001 \\
\hline 1 & $(.000)^{* *}$ & $(.000)^{* *}$ \\
\hline & .822 & .815 \\
\hline 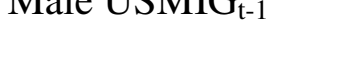 & $(.016)^{* *}$ & $(.017)^{* *}$ \\
\hline Female USMIG $\mathrm{US}_{\mathrm{t}-1}$ & & $\begin{array}{c}.068 \\
(.042)\end{array}$ \\
\hline NAFTA & & $\begin{array}{c}-.006 \\
(.002)^{* *}\end{array}$ \\
\hline IRCA & & $\begin{array}{c}-.002 \\
(.001)^{*}\end{array}$ \\
\hline$\%$ Change Border & & .010 \\
\hline Control & & $(.002)^{* *}$ \\
\hline$\%$ Change ER & & $\begin{array}{c}.012 \\
(.004)^{* *}\end{array}$ \\
\hline$\%$ Change MGDP & & $\begin{array}{c}.023 \\
(.015)\end{array}$ \\
\hline$\%$ Change US GDP & & $\begin{array}{c}.042 \\
(.019) * *\end{array}$ \\
\hline $\mathrm{R}^{2}$ & .947 & .948 \\
\hline $\begin{array}{l}\text { Dependent Variable: } \\
\text { All models were esti } \\
\mathrm{N}=1759 . * * \text { Significa }\end{array}$ & $\begin{array}{l}\text { male in } \\
\text { fixed e } \\
\text { Signific }\end{array}$ & \\
\hline
\end{tabular}




\section{References}

Borjas, George. 2002. The Impact of Welfare Reform on Immigrant Welfare Use. Center for Immigration Studies Report (http://www.cis.org/articles/2002/borjas.htm) (March).

Grieco, Elizabeth and Brian Ray, "Mexican Immigrants in the US Labor Force," Migration Information Source, March 1, 2004.

Judson, R. A. and A. L. Owen "Estimating Dynamic Panel Data Models: A Guide for Macroeconomists." Econometric Letters, 65(1999):9-15.

Kossoudji, Sherrie A. "Playing Cat and Mouse at the U.S.-Mexican Border." Demography 29 (1992):159-80.

Levy, S. and S. van Wijnbergen. Mexican agriculture in the free trade agreement: Transition Problems in Economic Reform, OECD Development Centre, Technical Papers No. 63, 1992.

Lucas, R.E.B. and Stark, O. "Motivations to Remit: Evidence from Botswana," Journal of Political Economy 93(1985):901-918.

Martin, P.L. Trade and Migration: NAFTA and Agriculture. Washington, D.C.: Institute for International Economics, 1993.

Martin, Philip. 2003. Promise Unfulfilled: Unions, Immigration, and Farm Workers. Ithaca. Cornell University Press. www.cornellpress.cornell.edu/, Chapter 7.

Martin, P.L., W. Huffman, R. Emerson, R.I. Rochin, and J.E. Taylor. Immigration Reform and U.S. Agriculture. Oakland: Division of Agriculture and Natural Resources, 1985.

Mincer, Jacob. Schooling, Experience, and Earnings. New York: Columbia University Press, 1974.

Munshi, Kaivan. "Networks in the Modern Economy: Mexican Migrants in the U.S.

Labor Market." Quarterly Journal of Economics 18(2003):549-599.

Public Policy Institute of California. "Has Increased Border Enforcement Reduced Unauthorized Immigration?” Research Brief, Issue \#61, July 2002.

Robinson, S., M.E. Burfisher, R. Hinojosa-Ojeda and K.E. Thierfelder. "Agricultural Policies and Migration in a U.S.-Mexico Free Trade Area: A Computable General Equilibrium Analysis." UC Berkeley, Department of Agricultural and Resource Economics Working Paper No. 617, December, 1991.

Singer, Audrey, and Douglas S. Massey. "The Social Process of Undocumented Border Crossing Among Mexican Migrants.” International Migration Review 32 (1998): 561-92.

Smith, James P. and Duncan Thomas, "Remembrances of things past: test-retest reliability of retrospective migration histories." Journal of Royal Statistics Soceit, 166(2003):23-49. 
Taylor, J. Edward. "Undocumented Mexico-U.S. Migration and the Returns to Households in Rural Mexico.” American Journal of Agricultural Economics, 69(1987):626-38.

Thilmany, Dawn. "FLC usage among California growers under IRCA: an empirical analysis of farm labor market risk management." American Journal of Agricultural Economics 78(1996):946-60.

Torok, S. J. and Wallace Huffman. "U.S. - Mexican Trade in Winter Vegetables and Illegal Immigration." American Journal of Agricultural Economics , 68(1986):246-260.

United States Commission on Immigration Reform, Migration Between Mexico and the United States: Binational Study, Editorial y Litografia Regina de los Angeles, S.A., Mexico City), 1997.

U.S. Commission for the Study of International Migration and Cooperative Economic Development (USCSIMCED). 1990. Unauthorized Migration: An Economic Development Response. Washington, D.C.

United States Department of Labor. Findings from the National Agricultural Workers Survey (NAWS) 1997-1998: A Demographic and Employment Profile of United States Farmworkers. Washington, DC: U.S. Department of Labor, Office of the Assistant Secretary for Policy, Office of Program Economics, Research Report No. 8, 2000. Findings from the National Agricultural Workers Survey (NAWS)

1990: A Demographic and Employment Profile of Perishable Crop Farm Workers. Washington, DC: U.S. Department of Labor, Office of the Assistant Secretary for Policy, Office of Program Economics, Research Report No. 8, 1991.

Yunez-Naude, A, "The Dismantling of CONASUPO, a Mexican State Trader in Agriculture", The World Economy, Vol. 26, No. 1, 2003, pp. 97-122.

Yunez Naude, A. and F. Barceinas Paredes, "Agricultural Trade and NAFTA: The Case of Mexico", in Kevin C. Kennedy (Ed.), The First Decade of NAFTA: The Future of Free Trade in North America, Transnational Publishers, Inc., New York, Dec. 2004, \#\# pp. 